
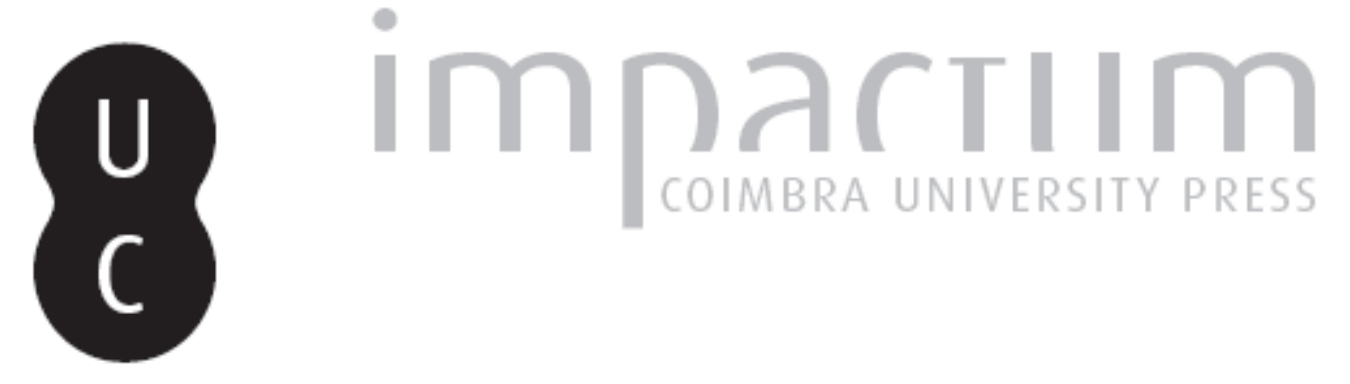

\title{
A ideia de filosofia no Brasil
}

\section{Autor(es): $\quad$ Cerqueira, Luiz Alberto}
Publicado por: Faculdade de Letras da Universidade de Coimbra, Instituto de Estudos Filosóficos

URL persistente:

URl:http://hdl.handle.net/10316.2/29611

DOI:

DOI:http://dx.doi.org/10.14195/0872-0851_39_6

Accessed : $\quad$ 26-Apr-2023 14:08:46

A navegação consulta e descarregamento dos títulos inseridos nas Bibliotecas Digitais UC Digitalis, UC Pombalina e UC Impactum, pressupõem a aceitação plena e sem reservas dos Termos e Condições de Uso destas Bibliotecas Digitais, disponíveis em https://digitalis.uc.pt/pt-pt/termos.

Conforme exposto nos referidos Termos e Condições de Uso, o descarregamento de títulos de acesso restrito requer uma licença válida de autorização devendo o utilizador aceder ao(s) documento(s) a partir de um endereço de IP da instituição detentora da supramencionada licença.

Ao utilizador é apenas permitido o descarregamento para uso pessoal, pelo que o emprego do(s) título(s) descarregado(s) para outro fim, designadamente comercial, carece de autorização do respetivo autor ou editor da obra.

Na medida em que todas as obras da UC Digitalis se encontram protegidas pelo Código do Direito de Autor e Direitos Conexos e demais legislação aplicável, toda a cópia, parcial ou total, deste documento, nos casos em que é legalmente admitida, deverá conter ou fazer-se acompanhar por este aviso.

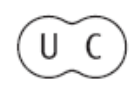




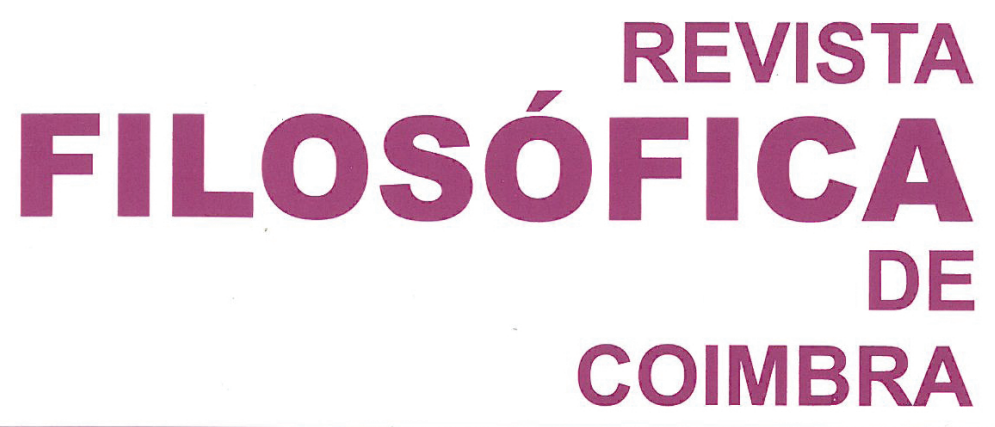

vol. 20 - número 39 - março 2011

vol. 20 - número 39 - março 2011

Fundação Eng. António de Almeida

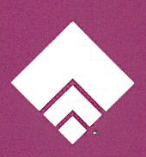




\title{
A IDEIA DE FILOSOFIA NO BRASIL
}

\author{
LUIZ ALBERTO CERQUEIRA*
}

Resumo: Na história da filosofia no Brasil, o estudo do aristotelismo da Ratio Studiorum é necessário para o conceito de filosofia "brasileira" no mesmo sentido em que se concebe, na história da filosofia ocidental, que a filosofia "moderna" emancipou o uso teórico da razão da tutela da teologia. A filosofia só ganha nacionalidade brasileira a partir do século XIX, mediante um processo simultâneo de assimilação da filosofia moderna e emancipação do próprio uso teórico da razão. O fato que marca o nascimento da filosofia brasileira é a introdução da liberdade como princípio de ação.

Palavras-Chave: Filosofia no Brasil; filosofia brasileira; aristotelismo no Brasil; modernização no Brasil

\begin{abstract}
In the history of philosophy in Brazil, the study of Aristotelianism in the Ratio Studiorum is necessary for the concept of "Brazilian" philosophy in the same way that it is conceived, in the history of Western philosophy, that "modern" philosophy emancipated the theoretical use of reason from the tutelage of theology. Philosophy only receives Brazilian nationality in the nineteenth century, through a simultaneous process of assimilation of modern philosophy and emancipation of own theoretical use of reason. The fact that marks the birth of the Brazilian philosophy is the introduction of freedom as a principle of action.
\end{abstract}

Key-words: Philosophy in Brazil, Brazilian philosophy, Aristotelianism in Brazil; modernization in Brazil

* Coordenador do Centro de Filosofia Brasileira do Programa de Pós-graduação em Filosofia da Universidade Federal do Rio de Janeiro.

http://filosofiabrasileiracefib.blogspot.com

cerqueira@ifcs.ufrj.br 


\section{Introdução}

A ideia de filosofia no Brasil remonta à reforma da universidade portuguesa no século XVI. Em 1555, o rei D. João III confiou aos jesuítas o Colégio das Artes, por ele fundado em 1548 junto à Universidade de Coimbra e destinado ao ensino de latinidade e filosofia. A partir de então, os jesuítas assumiram inteiramente o controle da instrução pública no reino de Portugal, o que perdurou até as reformas realizadas na segunda metade do século XVIII. Essa consideração histórica é fundamental para compreendermos por que o ensino oficial de filosofia no Brasil Colônia se deu, ao longo de dois séculos, sob a vigência da Ratio Studiorum, método pedagógico da Companhia de Jesus que estabelecia o que e como ensinar.

Mas independentemente do perfil escolástico da missão educativa da Companhia de Jesus, aferrando-se à tutela da teologia sobre a filosofia; e do seu papel político na Contrarreforma; e das razões teológicas que levaram os jesuítas a participar na defesa do liberum arbitrium contra a tese de Lutero "De servo arbitrio" (1525); convém ressaltar que o aristotelismo de filósofos jesuítas como Luis de Molina, Pedro da Fonseca e Francisco Suárez não corresponde exatamente àquele da Escolástica. O caráter filosófico da renovação do aristotelismo no século XVI é a exigência de rigor na fidelidade a Aristóteles, cujo pensamento fora considerado falseado pelas interpretações e interpolações nas sucessivas transmissões, recepções e adaptações do corpus aristotélico.

Apoiada na invenção da imprensa, tal exigência de rigor originou na Universidade de Coimbra um empreendimento inovador, o Curso Conimbricense (http://saavedrafajardo.um.es/WEB/archivos/Conimbricenses_Presentacion.pdf), pelo qual os mestres jesuítas estabeleceram a exegese de texto como princípio de validade objetiva do estudo filosófico. Para tanto, eles procederam do seguinte modo: (i) o estabelecimento do texto aristotélico original, (ii) a sua tradução para o latim e (iii) a publicação do texto precedido de um comentário sobre o seu conteúdo.

$\mathrm{O}$ aristotelismo dos filósofos jesuítas no século XVI contém formalmente o aristotelismo discriminado nas Regras do Professor de Filosofia da Ratio Studiorum. Na história da filosofia no Brasil, o estudo desse aristotelismo é necessário para o conceito de filosofia "brasileira" no mesmo sentido em que se concebe, na história da filosofia ocidental, que a filosofia "moderna" emancipou o uso teórico da razão da tutela da teologia. 


\section{O aristotelismo em Portugal}

A implantação do trivium (gramática, retórica e dialética), e a adaptação da lógica aristotélica aos objetivos específicos da formação religiosa, assinala em Portugal a projeção do aristotelismo como atitude sintonizada com o espírito do tempo, à semelhança do que já ocorrera em outras partes da cristandade europeia, desde Boécio. Após a fundação da universidade portuguesa (1290), Aristóteles continuou a ser objeto de estudo na disciplina Dialética, que no decurso do tempo passou a receber também as denominações de "Lógica" e "Súmulas", designação que provavelmente se universalizou por causa do sucesso das Summulae logicales, nome pelo qual ficou conhecido o Tractatus de Pedro Hispano.

A partir das obras dos Príncipes de Avis, no século XV, podemos verificar o uso das obras filosóficas de Aristóteles com vistas à fundamentação da ordem social e política, caracterizando-se assim os primórdios do aristotelismo em Portugal. O apogeu, de meados do século XVI a meados do século XVII, é marcado pelo projeto de renovação do estudo aristotélico na universidade (Coimbra e Évora), quando avulta a contribuição pessoal de Pedro da Fonseca, celebrado na história da filosofia em Portugal como o "Aristóteles português". Ao apogeu sobrevém a decadência, marcada pela abertura à filosofia moderna, quando sobressai a figura de Luís António Verney.

\subsection{Primórdios: a construção de uma doutrina de base aristotélica}

A introdução do estudo da doutrina aristotélica na universidade deu-se no século XV sob a dinastia de Avis. Seu responsável foi o Infante D. Henrique (1394-1460), que completou o ensino das artes liberais com as disciplinas do quadrivium (aritmética, geometria, astronomia e música) e criou as cátedras de filosofia natural e filosofia moral, sendo esta inspirada na Ética a Nicômaco, e aquela nos tratados da física de Aristóteles. Embora estivesse em conformidade com a decisão papal de 1366, que tornou obrigatório o estudo de Aristóteles no ensino público de filosofia, a atitude de D. Henrique revela as condições da universidade portuguesa: o descompasso em relação aos centros de referência na Europa - as universidades de Paris e de Oxford - e a ineficácia na formação de servidores para o Estado e para a Igreja. O próprio rei, D. João I (1357-1433), citando uma passagem do livro III do tratado De anima de Aristóteles, já chamara a atenção para a qualidade dessa formação em seu livro $D a$ montaria (D. JOÃO 1981, p. 57). 
Coube ao Infante D. Pedro (1392-1449), em famosa carta enviada de Bruges ao irmão D. Duarte (1391-1438), que então sucedera ao pai D. João I, ressaltar a necessidade de reforma da universidade. Refletindo as tendências gerais da filosofia do Renascimento, ele expõe suas ideias com vistas à ação imediata do homem, e defende uma posição prática diante do mundo e da realidade espiritual e moral. Em sua obra mais importante, o tratado Da virtuosa benfeitoria, ele procura estabelecer um conceito do dever (officium) sem prejuízo da liberdade de arbítrio, ao defender a política do benefício e definir os súditos ideais como "homens livres em obediência desejosa" (D. PEDRO 1981, p. 567). Referências básicas são a Política e a Ética a Nicômaco, de Aristóteles, e o Regimento dos príncipes (De regimine principum), de Tomás de Aquino e Ptolomeu de Lucca. Mas a inspiração para escrever o tratado veio de Cícero, cujo De officiis traduziu; e também de Sêneca e seu De beneficiis.

D. Duarte destacou-se pela observância do princípio aristotélico-tomista de que nihil est in intellectu quod non prius fuerit in sensu. Nessa perspectiva, a obtenção do saber não implica abstração mediante exclusão das sensações e sentimentos de que se reveste a presença das coisas à consciência. A evidência dessa orientação se encontra tanto no prefácio de sua obra mais conhecida, o Leal conselheiro, onde ele esclarece que o texto reflete seu pensamento acerca do vivido, e não o "estudo de livros nem ensino de letrados", como também na sua famosa conceituação da saudade como "um sentido que vem da sensibilidade, e não da razão" (D. DUARTE 1981, p. 287).

\subsection{Apogeu: a renovação do aristotelismo em Pedro da Fonseca}

No intuito de manterem-se fiéis à doutrina de Aristóteles e aos seus comentadores mais qualificados, os filósofos jesuítas não podiam prescindir de uma metodologia já consagrada no decurso de muitos séculos de especulação filosófica. Mas isso não impediu que eles soubessem conciliar o propósito de rigor com a exigência humanística da liberdade de arbítrio como princípio da dignidade do homem.

Nesse quadro merece destaque o português Pedro da Fonseca (1528-1599), cuja obra mais importante pela extensão, construção e, sobretudo, pelas ideias novas são os Commentariorum in libros Metaphysicorum Aristotelis (Comentários à Metafísica de Aristóteles), realizados segundo o sistema escolástico das quaestiones, mas partindo do texto original estabelecido pelo próprio Fonseca. Todavia, sua obra de maior repercussão na história do ensino filosófico ocidental são as Institutionum dialecticarum libri octo (Instituições dialéticas), que teve pelo menos 53 edições no 
período de 1564 a 1625 . Vale observar que entre as Regras do Professor de Filosofia na Ratio Studiorum encontramos a de $\mathrm{n}^{\circ}$ 9, que recomenda o uso do manual de Fonseca no início do curso. Das suas obras conhecidas, temos ainda a Isagoge philosophica, uma introdução à Filosofia concebida para substituir a Isagoge de Porfírio, mediante um estudo sobre o conceito de universal acrescentado ao estudo dos cinco predicáveis (gênero, espécie, diferença, próprio e acidente) nas Categorias de Aristóteles.

$\mathrm{O}$ aspecto mais característico de suas Instituições dialéticas é o da adoção da metodologia da lógica tópica. Antes mesmo de Descartes, o problema do método ocupa uma posição significativa em Fonseca. Não temos dúvida de que esta percepção do estudo da lógica encontra-se intimamente associada ao ambiente cultural da época, em que as preocupações referentes aos problemas práticos da vida humana se sobrepunham ao caráter meramente formal das "disputas" escolásticas. O que importava era de fato a constituição de uma lógica que servisse de instrumento útil nos domínios político, jurídico e pedagógico, onde as questões a resolver são controversas e por isso não suscetíveis de soluções categóricas e absolutas. A importância da obra de Fonseca está em mostrar que a dialética não é uma forma estéril de estudo filosófico circunscrita à demonstrabilidade da argumentação. Para ele, a dialética tem um compromisso com a verdade, sendo inteiramente solidária da analítica como seu instrumento. E foi assim que Fonseca pôde superar o probabilismo dos "dialéticos" (Valla, Agrícola, Vives, Petrus Ramus) e salvar o conceito aristotélico de ciência, se considerarmos que Aristóteles concebeu a dialética como útil e necessária à ciência, na medida em que somente a partir de proposições "prováveis" todo o homem pode participar diretamente na descoberta da verdade.

Nos Comentários, Fonseca procurou conciliar tomismo e escotismo, de maneira que atendeu às objeções de Duns Escoto ao tomismo, mas sem prejuízo da síntese de São Tomás. Para ele, o conceito formal do ser é unívoco, e não analógico, em sua referência à realidade singular das coisas. Se o objeto da metafísica é o ser enquanto ser, comum ao Criador e às criaturas, não há lugar para uma abstração que possibilite uma metafísica especial do Criador, distinta da metafísica da criatura (FONSECA, Comment. IV, c. 1, q. 1, s. 2). Neste sentido, ele distinguiu rigorosamente a metafísica da teologia e deu grande ênfase à unidade de essência do ser, no que influenciou Francisco Suárez.

Quanto à distinção entre essência e existência, para ele essa distinção é só de razão, correspondendo apenas aos dois modos do ser, sendo a essência o modo necessário, intrínseco à natureza de uma coisa, e a existência o modo contingente que se acrescenta a esta natureza (ibidem, c. 2, q. 4, s. 2). Tal distinção torna Fonseca parcialmente responsável 
pela introdução da terminologia dos modos na metafísica moderna. Sua independência de pensamento leva-o a afastar-se do tomismo oficial, ao rejeitar, por exemplo, a matéria assinalada (materia quantitate signata), segundo a definição de São Tomás, como princípio de individuação. Para São Tomás, na perspectiva da igualdade de essência das coisas, o princípio de individuação não seria mais que o princípio de multiplicação da mesma forma. Não podendo uma só e mesma forma por si mesma multiplicar-se, a multiplicação só se explicaria por algo que lhe adviesse e que fosse, ao mesmo tempo, intrínseco ao ser. Este algo seria a matéria enquanto se dá a conhecer pela quantidade. E como somente as coisas materiais têm esta propriedade quantitativa ou dimensiva, somente as coisas materiais poderiam ser diferentes entre si, sem prejuízo de sua identidade ontológica. Neste ponto, Fonseca não diverge da tradição tomista. Para ele, a diferença propriamente dita é a diversidade das coisas, mas de maneira que, não obstante tal diversidade, elas são absolutamente da mesma natureza. Entretanto, orientando-se pela tradição escotista, ele entende que a individuação se deve ao acréscimo de uma diferença positiva à essência de uma coisa, sendo o princípio de individuação simplesmente o princípio intrínseco pelo qual o indivíduo excede a própria condição de espécie ínfima. Portanto, já constando formalmente a espécie nos diferentes homens, e não podendo um homem tornar-se indiviso, ou indivíduo (individuum), nem pela matéria nem pela forma, conclui Fonseca que um homem se individua por qualquer outra coisa intrínseca que, à maneira da diferença específica, chama de diferença individual, porque sendo a diferença específica aquilo pelo qual a espécie excede o gênero, do mesmo modo se pode dizer que a diferença individual excede a espécie ínfima. Em outras palavras, assim como o homem, na sua essência, tem mais que o animal o fato de ser dotado de razão, do mesmo modo Sócrates, na sua essência individual, supera a essência comum aos diferentes homens pelo fato de ser este homem singular e determinado.

Contra o aristotelismo dogmático, Fonseca questionou o número de causas. Sem dizer abertamente que as causas são cinco, e não apenas quatro (formal, material, eficiente e final), acrescentou outro gênero, a causa exemplar, com base no conceito aristotélico da imitação ( $\mu i ́ \mu \eta \sigma \iota \varsigma)$. Assim como Aristóteles faz uma distinção entre matéria e forma, e da forma se pode dizer que é "interna" enquanto visão inteligível dos objetos dos nossos sentidos, do mesmo modo ele faz uma distinção entre corpo e alma; e por extensão se pode dizer que a alma é a "forma interna" da vida, não só como a condição da existência (a alma como causa e primeiro princípio do corpo vivente), mas também como o fim da composição corpo/alma. Mas Aristóteles admite dois sentidos para esse fim: por um lado, a morte, a decomposição como uma determinação da própria natureza; 
por outro, aquilo que é visado na procriação de semelhantes. Portanto, de acordo com o entendimento de Fonseca, é pela reprodução da espécie que a alma supera o determinismo da própria natureza e como que se reveste de uma condição divina e criadora. Neste sentido, a reprodução da vida pressupõe o exemplar como sua "forma externa", e segundo a definição de Fonseca, causa exemplar é a forma externa por cuja imitação se faz uma coisa (FONSECA 1964, p. 295).

Mas acima de todas essas análises e sutis considerações, o caráter construtivo e positivo do trabalho filosófico de Fonseca revela-se na novidade da célebre doutrina da ciência condicionada ou "ciência média" (scientia media), conforme sua afirmação de que "não houve até agora quem conciliasse deste modo claro e (como se costuma dizer) em termos próprios a liberdade do nosso arbítrio e a divina presciência ou providência" (FONSECA, Comment. III, VI, c. II, q. IV, s. VIII).

No tempo de Fonseca, a tradição tomista consagrara duas concepções de ciência divina: a de simples inteligência (simplicis intelligentiae) e a de visão (scientia visionis). Segundo São Tomás, o Criador é capaz de ver tudo o que de fato vai acontecer no mundo, como futuros absolutos, porque conhece previamente, em seu pensamento, todas as possibilidades de ação. A passagem do estado de pura possibilidade ao de futuro absoluto se explica pelo modo necessário da vontade divina. Como o modo necessário da vontade divina é conveniente ao agir humano, especialmente no caso das leis morais, impõe-se uma questão. Como justificar o mérito humano nas ações virtuosas ou morais, sem a livre escolha? Para conciliar a presciência divina e a liberdade humana, Fonseca introduziu entre as duas concepções de ciência divina a de ciência condicionada ou média. "Média" não só no sentido de que medeia entre as outras duas concepções, mas também porque delas participaria da seguinte forma: assim como o Criador conhece $a$ priori, pela simples inteligência, todas as possibilidades de ação no mundo, a ciência média corresponderia ao exame a priori da transformação dessas possibilidades em ações necessárias, isto é, "veria" como um mundo possível se atualiza necessariamente no tempo e no espaço. Como somente um de infinitos mundos possíveis ultrapassa os limites da possibilidade e da futuribilidade para se transformar em mundo atual (que o Criador previamente contempla), Fonseca procurou reduzir o problema dos futuros contingentes à questão da liberdade de escolha. Teoricamente, o ato de livre escolha diante de possibilidades contrárias é a condição (da parte do Criador e das criaturas) dessa transformação, configurando-se assim o caráter condicionado e relativo dessa ciência em toda a criação.

Aqui entra também, como componente teórica importante, a doutrina do tempo e do espaço imaginários. Segundo essa doutrina, Deus encon- 
tra-se no tempo e no espaço imaginários, participando, assim, em toda a transformação possível. Mas no caso da transformação promovida pela escolha humana, qual o sentido dessa participação divina? Esse sentido corresponde àquele mesmo sentido de participação na lei divina pela criatura racional, conforme a explicação de São Tomás (Sum. theol. I-II, q. XCI, a. II). E assim sendo, a participação na presciência divina pela criatura racional seria a condição do mundo atual fundado na necessidade, mas sem prejuízo da liberdade humana.

A parte dos Comentários que trata desses problemas só foi publicada após a morte de Fonseca. Mas independentemente de questões de ordem textual, e da controvérsia sobre a autoria da "ciência média" — geralmente vinculada a Luis de Molina e sua Concordia (1588) —, importa atentar no alcance da sua concepção de liberdade com vistas à filosofia moderna.

\subsection{Decadência}

O aristotelismo desenvolvido no século XVI em Portugal, e disseminado com êxito pelo Cursus Conimbricensis, entra em decadência a partir da segunda metade do século XVII, a despeito do empenho de Francisco Soares Lusitano (Cursus philosophicus, 1651), Inácio Carvalho (Compendium logicae conimbricensis, 1677) e Antônio Cordeiro (Cursus philosophicus conimbricensis, 1714). Nestes autores, a atenção nos "modernos" (recentiores) não serve senão para corromper o essencial daquela renovação filosófica: a exigência de rigor. A atitude que então se verifica é o ecletismo enquanto tentativa obstinada de conservar o sistema de ensino dos jesuítas, o que explica uma sobrevida da fidelidade a Aristóteles em face da introdução dos modernos conceitos de natureza e de método. A completa superação dessa resistência só se tornou possível mediante a assimilação da atitude iluminista.

\subsubsection{Ecletismo}

No século XVIII, acentuou-se a perversão do aristotelismo conimbri-

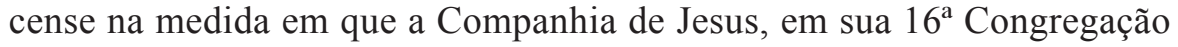
Geral (1730-1731), sancionou uma abertura à filosofia moderna, partindo do princípio de que as explicações dos fenômenos da natureza pelo método experimental não só não estão em oposição à doutrina aristotélica, mas com ela concordam perfeitamente. Essa abertura promoveu a presença política do "estrangeirado", nome pelo qual ficou conhecida a intelectualidade portuguesa que, ciosa de sua formação no estrangeiro (França, Inglaterra e Itália, principalmente), passou a denunciar como causa da 
decadência da cultura nacional o sistema de ensino dos jesuítas. Em resposta a esse jogo de forças políticas, configurou-se uma permeabilidade à filosofia moderna sob a forma do ecletismo, a exemplo da Philosophia universa eclectica (1754) de Inácio Soares. Outro exemplo é o da Philosophia libera seu eclectica rationalis et mechanica sensuum (1775) de Inácio Monteiro, que afirma ter percorrido e superado sucessivamente as divergências entre Aristóteles, Descartes, Gassendi e Newton, para concluir que nenhum sistema pode arrogar-se o direito da verdade absoluta e que só o ecletismo é a garantia de um pensamento livre.

A mesma abertura à filosofia moderna é defendida pelos padres seculares da Congregação do Oratório (em Portugal a partir da segunda metade do século XVII) até o momento da expulsão dos jesuítas (1759), a exemplo da Philosophia aristotelica restituta et illustrata qua experimentis qua raciociniis nuper inventis (1748) do padre João Baptista, pois ainda que lhe reconheçamos o propósito de abreviar e suprimir questões inoportunas no domínio da lógica, seu intuito de "restituir" a filosofia aristotélica não visa devolvê-la ao passado, senão reconduzi-la à condição de primazia.

\subsubsection{O Iluminismo português e a ideia de modernização: Verney}

A obra do estrangeirado Luís António Verney (1713-1792) é a principal referência do Iluminismo em Portugal. Depois de completar sua formação em teologia e direito em Roma, Verney decidiu denunciar a decadência da cultura nacional, tomando por alvo o método de ensino dos jesuítas e sua fundamentação filosófica, considerada por ele incompatível com a cultura moderna e inadequada à formação do espírito público. Esse estudo crítico, publicado anonimamente sob o título Verdadeiro método de estudar (1746), teve a sua primeira edição apreendida pela Inquisição e suscitou fervilhante polêmica.

Além deste primeiro livro, Verney produziu três manuais filosóficos "para uso dos jovens estudantes portugueses": De re Logica, De re metaphysica e De re physica. Tendo como referência o moderno empirismo, concentra-se inicialmente nas questões gnosiológicas e metodológicas concernentes à origem e natureza das ideias, aos critérios de verdade e aos processos de expressão e comunicação do pensamento. Sua ideia de natureza gira em torno ao caráter absoluto das "leis da natureza", cuja concepção pelos físicos modernos pressupõe uma visão matemática da existência como na mecânica de Newton. Neste sentido, a física mecânica implica o sentido de uma determinação superior e absoluta inerente à ideia do Criador, a qual, por isso mesmo, é reforçada apenas pela razão.

A metafísica é anunciada como uma teoria geral da ciência, incidindo quer sobre os seus fundamentos subjetivos, ao investigar o modo 
de conhecer as primeiras verdades ou princípios, quer sobre a estrutura da realidade conhecida, ao expor as verdades fundamentais comuns às diversas ciências com base na explicação causal: "nada existe no efeito que não exista na causa, ou de modo idêntico ou com maior perfeição" (VERNEY 2008, p. 336-38). De modo idêntico, segundo a forma e uma ordem de dependência, pela qual uma coisa está formalmente contida em outra logicamente anterior e dela depende, numa sucessão que, por isso mesmo, é um movimento mecânico; de um modo mais perfeito, segundo o fim e uma ordem de eminência, pela qual uma coisa está contida em outra como sendo aquilo para o qual tende a ser, de maneira que o que move não é um mecanismo, senão aquilo que é visado como fim, porque no plano da ação moral é o fim enquanto algo querido que move o agente. E este modo é mais perfeito porque não exclui o anterior, que é o modo da explicação científica, mas ultrapassa os seus limites. Neste último sentido, o modo mais perfeito tem um caráter metafísico. Assim se compreende em Verney a sua ênfase sobre a utilidade da Lógica e da Metafísica como disciplinas necessárias ao exercício da autoridade, pois na vida, como já ensinara Fonseca, não basta o conhecimento, senão também a virtude, para garantir a eficácia da ação (FONSECA 1964, p. 575).

Verney lutou para que seus manuais fossem adotados oficialmente, mas eles foram preteridos pelos de Antonio Genovesi (1712-1769). Entretanto, o Verdadeiro método de estudar teve grande divulgação nos setores extra-escolares, tanto no reino português como no espanhol, para o que contribuiu a sua tradução para o castelhano. No Brasil, é possível encontrá-lo em bibliotecas das mais diferentes ordens e congregações da época, nas diferentes regiões do país.

\section{A filosofia luso-brasileira}

A história da filosofia no Brasil pressupõe a extensão, da metrópole à colônia, das mesmas condições estabelecidas para o estudo filosófico em Portugal a partir do Colégio das Artes. Tais condições, sob a forma de recomendações estritas, se encontram na Ratio Studiorum, principalmente nas Regras do Professor de Filosofia. A primeira delas configura a tutela da teologia sobre a filosofia: "Como as artes e as ciências da natureza preparam a inteligência para a teologia e contribuem para a sua perfeita compreensão e aplicação prática, e por si mesmas concorrem para o mesmo fim, o professor, procurando sinceramente em todas as coisas a honra e a glória de Deus, trate-as com a diligência devida, de modo que prepare os seus alunos, sobretudo os nossos, para a teologia, e acima de tudo os estimule ao conhecimento do Criador" (COMPAÑ̃A DE JESÚS, p. 65). 
Nesse quadro, destacamos a obra do jesuíta Antônio Vieira (1608-1697), cuja formação se deu inteiramente no Brasil. Seus textos suscitam em nós o mais vivo interesse filosófico porque no estilo de criação da sua parenética, referido ao "barroco", o conhecimento de si é o primeiro na ordem do saber: "neste mundo racional do homem, o primeiro móbil de todas as nossas ações é o conhecimento de nós mesmos" (VIEIRA 2001, II, p. 529).

É deste ponto de vista que consideramos justificável o conceito de filosofia luso-brasileira: não como a mera reprodução da filosofia portuguesa no Brasil, senão como uma abertura nesse universo fechado com vistas ao uso emancipado da razão.

\subsection{Significado filosófico do barroco em Antônio Vieira}

Como expressão do barroco, o estilo de Vieira consiste tanto em sua técnica exemplar de construir o discurso mediante a interpretação do sentido das palavras, fazendo distinções conceituais, quanto pelo fato de que tais distinções não são procedimentos formais, senão o artifício arrevesado de inculcar princípios universais por meio de uma simples imagem suscitada por figuras de linguagem, especialmente a metáfora: "Que coisa é a conversão de uma alma senão entrar um homem dentro em si, e ver-se a si mesmo?" (VIEIRA 2001, I, p. 33); "quem vê o corpo, vê um animal; quem vê a alma, vê ao homem" (VIEIRA 2001, II, p. 533).

A fonte de pesquisa para os argumentos de Vieira é a lógica tópica dos filósofos jesuítas do século XVI, como Francisco de Toledo e Pedro da Fonseca, o qual observa, no lugar das causas, que à forma ou essência do ofício é inerente uma certa matéria, e que por isso mesmo deve ser acusado o orador que quiser compor o seu discurso de razões matemáticas ou filosóficas, sem recorrer às figuras de linguagem (FONSECA 1964, 515). Quanto à preferência pela imagem para inculcar um princípio universal, distinguimos em Vieira a mesma perspectiva filosófica que atribuímos aos príncipes de Avis, especialmente a D. Duarte no Leal conselheiro: o conhecimento visado não é o conceito abstrato, mas a vivência - a vivência religiosa - enquanto a presença do vivido à consciência como um sentido que vem da sensibilidade, pelas sensações e sentimentos, e não da razão.

\subsubsection{O conhecimento de si como princípio}

Referida ao calvário de Cristo, a vivência religiosa em Vieira é a consciência de estar formalmente submetido a um poder soberano em razão da própria natureza: assim como pela alma o homem recebeu o 
benefício do livre-arbítrio, tornando-se capaz de agir como quer, na mesma medida da Providência, pelo corpo ele paga por esse privilégio e padece o que não quer. Entretanto, pela consciência de si o homem "vê" a sua condição natural fora de si mesmo, tornando-se então capaz de transformar essa condição natural em condição moral, ao preferir pagar o tributo da natureza pelo benefício (o livre-arbítrio) que dela recebe, e não pela força: "não há tributo mais pesado que o da morte, e contudo todos o pagam, e ninguém se queixa; porque é tributo de todos" (VIEIRA 2001, II, p. 324).

Pela consciência de si, Vieira concebe dois modos do ser: (i) o modo formal ou essencial, em virtude do qual o fato de ser ou existir obriga o homem à própria natureza enquanto uma força estranha $\mathrm{e}$ absoluta, e (ii) o modo existencial, em virtude do qual ele escolhe e prefere imitar a natureza, obrigando a si mesmo pelo dever ou ofício cotidiano, de maneira que ao ser impõe-se o dever-ser como sendo o modo próprio do homem: "Não é necessária Filosofia para saber que um indivíduo não pode ter duas essências [...] Quis-nos ensinar Cristo Senhor nosso, que pelas conveniências do bem comum se hão de transformar os homens, e que hão de deixar de ser o que são por natureza, para serem o que devem ser por obrigação [...] porque o ofício há-se de transformar em natureza, a obrigação há-se de converter em essência" (idem, p. 325).

É com base nessas duas modalidades do ser que a orientação política de Vieira nas "questões de direito" se ajusta à tradição da Escola de Salamanca (Francisco de Vitória, Domingo de Soto), particularmente ao jesuíta Francisco Suárez (1548-1617), segundo o qual "de dois modos [...] pode-se dizer que algo pertence ao direito dos povos. De um modo, porque é o direito que todos os povos e as diversas gentes devem observar entre si; de outro modo, porque é o direito que as cidades, individualmente, ou os reinos observam dentro de seus próprios limites e que, por similitude e conveniência, é chamado de direito das gentes" (SUAREZ, De legibus ac Deo legislatore, II, c. 19, n. 20). Desse ponto de vista, Vieira reconhece ao índio brasileiro o direito à liberdade enquanto causa ou forma da vida inteiramente alheia à dos colonizadores portugueses; mas ele também reconhece aos mesmos colonizadores o direito ao uso da mão-de-obra escrava dos negros africanos oriundos dessa condição.

\subsubsection{A liberdade como indiferença}

A expressão "saber de salvação" no contexto da filosofia luso-brasileira frequentemente se constitui num mal-entendido. Em Vieira, o conhecimento de si é o primeiro na ordem do saber porque nele se funda a salvação 
da própria alma enquanto uma força poderosa de criação e de autoridade sobre as próprias ações: "livre a alma dos embaraços e dependências do corpo, obra com outras espécies, com outra luz, com outra liberdade [...] se a morte há de fazer por força esta separação, por que a não faremos nós por vontade? Por que não fará a razão desde logo, o que a morte há de fazer depois? Oh que vida! Oh que obras seriam as nossas tão outras do que são!" (VIEIRA 2001, II, p. 537). Mas em que sentido a razão há de promover essa liberdade?

A liberdade, como a conceberam os filósofos jesuítas do século XVI, envolve uma consideração específica sobre o conceito de livre-arbítrio ou liberdade de escolha (liberum arbitrium) introduzido pela filosofia cristã. Segundo Pedro da Fonseca, o caráter subjetivo da liberdade consiste na contingência de o indivíduo agir de maneira que pode agir também ao contrário. Tal contingência significa que a eficácia prevista não exclui a possibilidade oposta do erro, da falha, da decepção, enfim do pecado e da dor como efeitos da mesma causa. A conclusão imediata não é nova: nós nos enganamos e falhamos porque as nossas escolhas dependem do grau imperfeito do saber humano. Mas no contexto do Humanismo uma outra conclusão é inovadora: se a possibilidade do erro está formalmente contida no âmbito subjetivo da liberdade de escolha, então o próprio homem pode desenganar-se e corrigir-se, na medida em que ele esteja determinado a seguir o caminho que a razão universal lhe aponta. Por isso não surpreende que Fonseca ressalte a ideia de que a liberdade também é causa de não se fazer o melhor, sem prejuízo da mesma liberdade. Neste sentido, a essência da liberdade é a consciência de si absolutamente indiferente a querer ou não querer. Daí a sua conclusão de que a liberdade "radica" na razão, a qual nos permite tanto a previsão do fim desejado quanto a autodeterminação para a eficácia da ação. Tal compreensão levou Fonseca a definir liberdade como "faculdade da razão e da vontade", e razão como "regra das nossas ações" (FONSECA, Comment. III, IX, c. 2, q. 2-3).

Essa indiferença é o fundamento da psicologia jesuítica na preparação dos seus missionários para imitar o exemplo de Cristo e enfrentar com despojamento, coragem e esperança as imensas dificuldades nas terras de empreendimentos coloniais.

Vieira reflete com clareza esse conceito da liberdade como indiferença, quando propõe aos negros africanos escravizados em um engenho de açúcar na Bahia o conhecimento de si mesmos como imitadores de Cristo crucificado, o qual não só se liberta da prisão em que se encontra toda a alma atormentada pelo sofrimento físico, como também se salva como ente moral: "deveis dar infinitas graças a Deus por vos ter dado conhecimento de si, e por vos ter tirado de terras, onde vossos pais e vós vivíeis 
como gentios; e vos ter trazido a esta, onde instruídos na Fé, vivais como Cristãos, e vos salveis" (VIEIRA 2001, I, p. 646).

\subsection{A modernização como problema filosófico}

No século XVII, a emancipação do uso teórico da razão pelos filósofos "modernos" consagrou uma nova doutrina da liberdade. Considerado com justiça como o fundador da filosofia moderna, Descartes ensina nos Princípios da filosofia que a dúvida metódica tem o seu fundamento na liberdade, a qual, sendo tão evidente à consciência de si permite ao indivíduo impedir a si mesmo de crer naquilo que ainda não conhece com clareza. Era o que faltava, depois dos filósofos jesuítas, para desbastar o poder humano de arbítrio sobre as próprias ações do seu caráter contemplativo. Descartes reconhece a liberdade como indiferença, mas adverte nas Meditações que esta indiferença não justifica falta de determinação no agir, na medida em que ela se refere apenas à forma do conhecimento como um saber independente dos sentidos do corpo, "seja porque eu conheça com evidência o bom ou o verdadeiro [...] seja porque Deus disponha assim o interior do meu pensamento" (DESCARTES, Meditações, IV, 9). É neste sentido que ele define a indiferença como sendo "o mais baixo grau da liberdade" (idem, ibidem).

Em Portugal, coube a Luís António Verney, sob a influência do Iluminismo francês, a tarefa de mostrar a necessidade de assimilação da doutrina cartesiana da liberdade segundo as "leis" da razão universal, sem que para isso fosse preciso renunciar à "lei" de Deus.

$\mathrm{Na}$ história da filosofia no Brasil, a ideia de modernização pressupõe o caminho aberto por Verney, cujo Verdadeiro método de estudar certamente foi bem conhecido no Brasil. Depois da expulsão dos jesuítas e da supressão da Ratio Studiorum, quem se propôs a reforma do espírito brasileiro contemplativo e indiferente às grandes transformações culturais no mundo moderno foi Domingos José Gonçalves de Magalhães (1811-1882).

\section{O nascimento da filosofia brasileira}

A filosofia só ganha nacionalidade brasileira a partir do século XIX, mediante um processo simultâneo de assimilação da filosofia moderna e emancipação do próprio uso teórico da razão. As primeiras evidências desse processo histórico começam no final do século XVIII, quando o poeta Sousa Caldas publica uma Ode ao Homem Selvagem (1784), sob a influência da 
ideia de homem natural em Rousseau. Em 1800, o bispo Azeredo Coutinho funda o Seminário de Olinda, onde foram introduzidos estudos de física experimental, história natural e química. Em 1808, a corte portuguesa se transfere de Lisboa para o Rio de Janeiro em fuga da invasão napoleônica; nesse mesmo ano, Hipólito da Costa começa a publicar, em Londres, o periódico Correio Brasiliense (1808-1822), que passou a divulgar as ideias liberais. Nos anos de 1813 e 1814 são publicados, no Rio de Janeiro, 18 números de $O$ Patriota, periódico dedicado exclusivamente à difusão do conhecimento científico no Brasil. De 1813 a 1816, Silvestre Pinheiro Ferreira organiza e oferece no Rio de Janeiro, onde se encontra como membro da corte portuguesa, um curso ao estilo do empirismo de Verney, as Preleções filosóficas, nas quais ele se serve do sensualismo de Condillac para explicar a natureza do discurso, da linguagem e das ideias. Em 1816, a mudança de um grupo contratado de artistas acadêmicos franceses para a corte do Rio de Janeiro causará, nas décadas seguintes, profundo impacto na vida cultural brasileira. Dez anos após a declaração da Independência (1822), e uma vez consolidada a autonomia do país, Frei Francisco do Monte Alverne, famoso orador e estudioso da literatura francesa, encontra-se a lecionar filosofia em seminário no Rio de Janeiro, onde estimulou o jovem Gonçalves de Magalhães, recém-formado em medicina, a estudar o romantismo de Chateaubriand e o espiritualismo de Victor Cousin, como também a combater o sensualismo introduzido pelo magistério de Silvestre Pinheiro Ferreira.

Nessa fase inicial, destacamos o nome de Gonçalves de Magalhães por ter sido ele quem concebeu e implementou um projeto de mudança de método na maneira de pensar. Estabelecido em Paris (1833-1837), ele aprofundou seus conhecimentos de ciências da natureza e humanas na Sorbonne, estudou o espiritualismo francês, frequentou as aulas de Théodore Jouffroy, vivenciou o romantismo, e editou com os amigos Porto-Alegre e Torres Homem a Niterói, Revista Brasiliense (1836), onde publicou o Ensaio sobre a história da literatura do Brasil, no qual ele discorre sobre as condições da cultura brasileira e a necessidade de reforma da literatura, denunciando a doutrina aristotélica dos estilos, então decadente, pela qual se instituíra a imitação como fundamento de uma arte retórica de caráter supraindividual, anônimo e coletivo. Gonçalves de Magalhães inaugurou o romantismo brasileiro (Suspiros poéticos e saudades, poemas, 1836) e promoveu a reabilitação do indígena brasileiro como parte da população nacional. Seus principais textos filosóficos são: Filosofia da religião (1836), Fatos do espírito humano (1858) e A alma e o cérebro (1876). 


\subsection{Da conversão ao cogito cartesiano: a defesa do espiritualismo}

O fato que marca o nascimento da filosofia brasileira é a introdução da liberdade como princípio de ação. Segundo Vieira, pela conversão o indivíduo conhece a si mesmo preso ao determinismo das leis da natureza, descobrindo, porém, na própria indiferença ao mecanismo da necessidade uma via de escape dessa prisão. Tal indiferença, no entanto, se transforma em alienação na medida em que se transferem para o domínio do "reino de Deus" todas as aspirações de justiça no mundo da vida humana, resultando disto uma separação real, porquanto vivida, entre os dois domínios. Trata-se, portanto, de negar a indiferença. Neste sentido, e somente neste sentido, Gonçalves de Magalhães contrapõe a liberdade ao espírito contemplativo:

Podia Deus sem dúvida criar uma sociedade de espíritos puros, não obrigados a coisa alguma, não sujeitos à menor dor, seres angélicos que vivessem em uma eterna bem-aventurança, só contemplando as maravilhas do seu criador. Mas qual seria o mérito desses espíritos para tanta ventura? Necessita Deus de admiradores inúteis? [...] o que seria então a liberdade humana, se estivesse inteiramente subjugada a instintos naturais? Qual seria o nosso mérito, se nenhum obstáculo se nos apresentasse? O que seria a virtude, se a não praticássemos com algum esforço, vencendo as dificuldades e os vícios com que nos opomos uns aos outros? Qual seria a nossa ciência, quais as nossas artes, a nossa indústria, se as necessidades, as privações e as misérias humanas, a que chamamos males físicos e morais, não nos instigassem a uma contínua atividade livre, a um trabalho incessante? (MAGALHÃES 2004, p. 355-56)

Portanto, em Gonçalves de Magalhães a fé não é incompatível com a liberdade humana. Pelo contrário, nele o cristianismo, fundado na ideia do Criador, é o ponto de partida para justificar a busca da verdade e o trabalho de criação da vida civilizada como tarefas infinitas. Vemos assim que ele se encontra em perfeita sintonia com o pensamento de Descartes, quando este argumenta: "para que eu seja livre, não é necessário que eu seja indiferente na escolha de um ou de outro dos dois contrários; mas antes, quanto mais eu pender para um, seja porque eu conheça evidentemente que o bom e o verdadeiro aí se encontrem, seja porque Deus disponha assim o interior do meu pensamento, tanto mais livremente o escolherei e o abraçarei" (DESCARTES, Meditações, IV, 9).

O que define o espiritualismo de Gonçalves de Magalhães, em consonância com as ideias psicológicas de Maine de Biran, é a concepção de uma "ciência do espírito" separada do modelo causal de explicação 
mecânica das ciências da natureza. Essa concepção, entretanto, não implica desprezo pelo caráter científico do saber. Ao contrário, pela primeira vez na história da filosofia no Brasil alguém procura reunir provas recorrendo ao campo das modernas ciências da natureza. Mas a sua preocupação é repelir o sensualismo no mundo da vida, o que o leva a conceber uma surpreendente teoria da sensibilidade, a saber: as sensações não fazem parte do espírito senão como "sinais de alguma coisa", sendo o modo de percepção do espírito o que as reúne e conserva em memória, e o que "o faz parecer sensível" pela consciência de algo exterior (MAGALHÃES 2004, p. 185).

Importa assinalar que Gonçalves de Magalhães distingue como sendo irredutíveis entre si o domínio do espírito e o domínio dos fenômenos físicos, cabendo àquele a primazia na ordem do saber e da ação moral. Daí ser imperioso que "sirva o cérebro ao espírito como o piano ao artista que nele executa a música que tem na mente" (MAGALHÃES 1876, p. 32).

\subsubsection{A doutrina conservadora: a tese da conciliação}

Em 1762, Rousseau assinala na gênese do Estado moderno uma relação de reciprocidade entre o indivíduo e o poder constituído por convenção, de maneira que para servir à sua pátria o indivíduo abre mão de sua liberdade natural, e do direito natural ilimitado a tudo o que deseja e pode alcançar, para ganhar o direito civil de ser protegido contra toda dependência pessoal, sendo essa a sua condição de cidadão. Portanto, na condição de cidadão o homem não pode não ser livre (ROUSSEAU, $O$ contrato social I, VII-VIII). Tais ideias certamente marcaram o pensamento de Gonçalves de Magalhães em seu estágio em Paris, como parece evidente: "A economia política tem combatido vitoriosamente o erro [...] que um povo não pode prosperar senão à custa de outro povo [...] política essa que à imitação dos romanos [...] Portugal exerceu sobre o Brasil" (MAGALHÃES 2004, p. 388).

Mas ao mesmo tempo que assimila os conceitos iluministas de povo, pátria, nacionalidade e cidadania, e procura vincar o patriotismo como o fermento da reforma das instituições nacionais, parece que ele se encontra diante de uma Esfinge que lhe propõe o seguinte quebra-cabeça: descartar o modo de produção escravista, considerando-se que, embora errado, perigoso e moralmente condenável, o uso da população de origem africana como mão de obra escrava não era até então empecilho ao crescimento econômico do país.

Apropriando-se de uma tese de Grotius, muito provavelmente recolhida d'O contrato social de Rousseau, que a rejeita, Gonçalves de Magalhães supõe que se é possível um indivíduo alienar a sua liberdade e tornar- 
-se escravo de um senhor, então é possível toda uma população fazer o mesmo. Com base nessa suposição, ele justifica a existência de fato da sociedade brasileira como "uma sociedade de homens livres, que não exclui a outra, nem é por ela excluída" (MAGALHÃES 2004, p. 356), contribuindo assim para fortalecer a hegemonia da produção escravista exportadora voltada exclusivamente para o mercado externo, em detrimento do mercado interno cuja riqueza já apresentava sinais evidentes de expansão, e cuja força de trabalho poderia receber uma atenção que não fosse tão contrária ao desenvolvimento da indústria e das artes.

Baseado no modelo de explicação causal que dá conta da conservação da natureza, isto é, a causalidade formal, segundo a qual nada existe no efeito que não esteja formalmente contido na causa, Gonçalves de Magalhães não vê como reconhecer no mundo da vida a liberdade humana de escolha do que é para si o melhor e o mais perfeito e, ao mesmo tempo, justificar o acordo e a harmonia necessárias entre as partes de uma unidade orgânica, senão admitindo como causa da vida organizada em geral um princípio universal de conciliação espontânea, o "princípio vital", historicamente atribuído ao filósofo Plotino e recuperado por eminentes químicos e biólogos de sua época, como J. M. P. Flourens (MAGALHÃES 2004, p. 98).

A tese da conciliação, recheada de referências e citações de obras de prestigiados autores do campo da ciência, e apresentada como resposta para o enigma nacional da escravidão serviu de fundamento à velha concepção, em geral contraposta à ideia de revolução, de que a distância entre o filósofo e o político é imensa, na medida em que há reformas que o espírito prevê em um futuro remoto, ao passo que no presente combate como altamente prejudiciais.

\subsection{O cientificismo da escola do Recife}

O positivismo de Comte e a teoria de Darwin acerca da evolução das espécies por meio da seleção natural na luta pela vida (cuja publicação é simultânea à dos Fatos do espírito humano de Gonçalves de Magalhães) repercutiram no Brasil como instrumentos de combate político. $\mathrm{O}$ epicentro dessa agitação de ideias foi a escola de direito do Recife, onde se formaram Tobias Barreto (1839-1889) e Sílvio Romero (18511914), e onde o primeiro exerceu o seu magistério. O uso da ciência como um espelho imparcial para ver a condição histórico-cultural de si mesmo como povo caracterizou o cientificismo liderado pelos dois em um amplo programa de modernização cultural, incluindo a própria ideia de cultura. 
$\mathrm{Na}$ cidade do Recife, centro da região cujos produtores de açúcar de cana detinham na época a maior fatia do mercado mundial e cerca de $50 \%$ dos trabalhadores escravos no país, Tobias Barreto inaugurou a historiografia filosófica brasileira com o propósito de desqualificar cientificamente os autores representativos da consciência conservadora. O primeiro alvo não podia ser outro senão os Fatos do espírito humano, porque o seu autor, além de desfrutar de enorme prestígio literário na corte do Rio de Janeiro, onde também fora nomeado professor de filosofia, ocupava altas funções políticas e diplomáticas, tornara-se barão e visconde, e amigo do imperador D. Pedro II. Em artigo homônimo publicado no Correio Pernambucano (5-8/06/1869), Tobias Barreto refutou a teoria da sensibilidade ali apresentada como sendo "a face psicológica do tradicionalismo" e acusou Gonçalves de Magalhães de ser um diletante perigoso em matéria filosófica, cujos argumentos "se devem perseguir com apupos, como um parasita e como um inimigo". O outro alvo foi José Soriano de Souza, doutor em filosofia por Louvain, professor titular de filosofia no colégio mais importante da região, e autor das Lições de filosofia elementar, racional e moral (Recife, 1871), obra que ele considerou como um símbolo do "atraso" nacional do ponto de vista da historicidade da filosofia:

O ilustre doutor [...] Ainda julga que a sociedade moderna é teatro das velhas contendas entre a razão e a fé [...] O Dr. Soriano está muitíssimo atrasado [...] no meio do triunfo geral da ciência moderna [...] a questão filosófica mais inquietante, se não a de maior alcance, tem sido levantada sobre a própria essência e limites da filosofia (BARRETO 1990, p. 165).

$\mathrm{Na}$ corte do Rio de Janeiro, para onde se transferira, Sílvio Romero tornou-se professor de filosofia por concurso e destacado crítico literário. Ao romantismo religioso de Gonçalves de Magalhães, para quem a poesia tem um alcance sobrenatural, no sentido de que "deve de contínuo subir ao Senhor" (MAGALHÃES 1836, Prólogo "Lede"), Sílvio Romero contrapôs a ciência como limite, ao afirmar que a poesia "perdeu todos os ares de mistério, depois que a ciência $[\ldots]$ penetrou $[\ldots]$ no problema das origens $[. .$.$] A poesia [. .$.$] nada tem de absoluto, nem de sobrenatural"$ (ROMERO 1878a, Prólogo).

Do legado de Sílvio Romero resistiu por mais de um século, e ainda ressoa, a sua concepção historicista de que as ideias filosóficas dependem das condições histórico-culturais em que o homem conhece a si mesmo como povo. Em outras palavras, ou as ideias filosóficas têm a sua origem na história da cultura nacional ou não têm, mas indiferente às premissas a história universal da filosofia continua a sua marcha para o futuro. Assim, depois de convencer-se com Tobias Barreto sobre o "atraso" da filosofia 
no Brasil, ele concluiu que a única solução para a inteligência nacional seria buscar no estrangeiro a fonte de sua inspiração, filiando-se a autores estrangeiros:

Na evolução filosófica [da cultura alemã], Kant dá Fichte; este dá Schelling e, por uma razão imanente ao sistema, aparecem, ao mesmo tempo, Hegel e Schopenhauer [...] neste país, ao contrário, os fenômenos mentais seguem outra marcha; o espírito público não está ainda criado e muito menos o espírito científico [...] As ideias dos filósofos, que vou estudando, não descendem umas das dos outros [...] É que a fonte onde nutriam suas ideias é extranacional. Não é um prejuízo; antes equivale a uma vantagem. (ROMERO 1878b, p. 35-36).

\subsubsection{A cultura como antitese da natureza}

Assim como confessou, em carta de Paris, ter-se chocado com o "caráter muitas vezes horrível, pavoroso" do teatro romântico francês (assassinatos, incestos, etc.), Gonçalves de Magalhães também mostrou-se assustado com as condições humilhantes dos trabalhadores no novo mundo industrial, comparando-os a "escravos de raça branca", e chegando a afirmar que, embora considerasse admiráveis as conquistas econômicas da produção industrial, não via nesse trabalho operário a dignidade do homem. Para ele, os triunfos da ciência e as invenções da tecnologia e da arte, que constituem o mundo da cultura, não podem convir apenas às necessidades materiais, em detrimento das necessidades morais e da primazia do espírito sobre o corpo.

Tal manifestação de censura, refletindo uma resistência ao mundo exterior, quando se revela o espírito mediante o esforço de distinguir-se do que não é ele, está em perfeita sintonia com a ciência da alma de Maine de Biran; e de algum modo vai ao encontro da concepção educativa de Rousseau, em La nouvelle Héloüse, de que a consciência de si como povo e cidadão não pode gastar nem estragar a natureza humana.

Em sua Filosofia da religião, Gonçalves de Magalhães repete Victor Cousin quando afirma que, assim como a forma é a condição necessária da existência física, o homem, em seu passo seguinte ao seu estado de natureza, ele cria o culto para dar forma à religião natural e não esquecê-la; também assim, ele cria a arte para dar forma à beleza natural do espírito humano e conservá-la; e tudo se justificaria com base na explicação de que após o conhecimento de si como sendo criatura de Deus, o homem moral nada faz senão seguir a própria natureza.

Contra esta concepção Tobias Barreto argumenta que "os limites da moral [...] são sempre posteriores a um estado de ilimitação e irregula- 
ridade, que no todo, ou em parte, é o primitivo estado natural. Logo o seguir a natureza, em vez de ser o fundamento da moral, pelo contrário é a fonte última de toda imoralidade" (BARRETO 1990, p. 305). Para melhor compreensão disto, considere-se o seu exemplo a propósito da sociedade escravista brasileira de sua época:

[...] se alguém hoje ainda ousa repetir com Aristóteles que há homens nascidos para escravos, não vejo motivo de estranheza. Sim, é natural a existência da escravidão; há até espécies de formigas, como a polyerga rubescens, que são escravocratas; porém é cultural que a escravidão não exista. (idem, p. 304)

Ao argumento da naturalidade Tobias Barreto contrapõe o da historicidade no que diz respeito às necessidades do espírito, e à própria ideia do espírito, principalmente quando "se imagina que uma crença, uma opinião, há longo tempo alimentada, não possa ser abatida pelos esforços da razão, senão mediante operações intelectuais, capazes de convencer-nos da fraqueza de nossas ideias anteriores" (idem, p. 141).

Sob a influência de Kant, ele assume como princípio que todo o conhecimento humano é relativo, que na essência dos objetos cognoscíveis há alguma coisa que os prende ao sujeito de conhecimento, uma originária adaptação daqueles ao entendimento deste. Assim, tanto quanto lhe parece necessário evitar que o espírito se torne refém das próprias crenças, isto é, se naturalize, também lhe parece evidente na história da humanidade a luta pela existência social contra a luta pela existência natural. Se a natureza se desenvolve como um absoluto, segundo uma causalidade mecânica que lhe é imanente, as necessidades do espírito se justificam diferentemente por uma causalidade final (e não formal), considerando-se a capacidade que tem o homem de realizar um plano por ele mesmo traçado, de atingir um fim que ele mesmo se propõe. Por isso, contrariamente à ideia de não gastar a natureza, a essência da cultura consiste em desbastar o espírito da natureza, adaptando-o a princípios e valores. Daí a sua definição da cultura como "a antítese da natureza, no tanto quanto ela importa uma mudança do natural, no intuito de fazê-lo belo e bom" (idem, p. 247); daí também a sua definição da liberdade como "uma conquista, um hábito ou um jeito, que o homem adquire, de dirigir seus atos para um alvo real ou ideal, por ele prefigurado, e quase sempre em oposição ao pendor da natureza, da mesma forma que se pode adquirir o hábito de nadar contra as correntes" (idem, p. 310). 


\subsection{A ideia de filosofia como ciência do espírito}

Ao fazer a crítica dos fundamentos psicológicos do espiritualismo adotado por Gonçalves de Magalhães, Tobias Barreto consolida a ideia da modernização no Brasil e abre em definitivo a perspectiva de uma filosofia brasileira.

Parece-lhe evidente que a noção do "sentimento do esforço", enquanto um "fato primitivo" do "senso íntimo" na psicologia de Maine de Biran, remonta à doutrina cartesiana no que esta se refere ao poder livre de autodeterminação na vontade, o qual depende da razão no sentido de que podemos agir de maneira que "não sentimos absolutamente que alguma força exterior nos obrigue a tanto" (DESCARTES, Meditações, IV, 9).

Mas o homem não é só a consciência de si como razão ou pensamento, argumenta Tobias Barreto; é ainda, e principalmente, a consciência de si como sociedade, como povo. Seria pobre a definição do homem como animal racional, ou como uma coisa que pensa, senão como um animal que tem "a capacidade de conceber um fim e dirigir para ele as próprias ações, sujeitando-as destarte a uma norma de proceder (BARRETO 1990, p. 302). Portanto, além do caráter imanente do espírito em sua interioridade, deve considerar-se principalmente o seu caráter transcendente quanto à exterioridade do fim que o move na ação moral. Em suma: "a consciência não é sempre intérprete fiel do mundo interior" (idem, p. 142). Mas por outro lado, diz ele no mesmo texto, "há sérios motivos de lançar em dúvida a eficácia do meio empregado para o homem conhecer-se de um modo objetivo e científico", segundo o método experimental da física.

Tobias Barreto entende que a eficácia da ação livre envolve uma norma de proceder, isto é, uma causalidade eficiente, mas é muito claro quando esclarece que "dizer que a liberdade tem leis não é negá-la [...] não é reduzir o processo da vida moral à pura mecânica dos átomos, a ações e reações químicas" (idem, p. 294).

Neste ponto, o autor brasileiro diverge inteiramente da interpretação dada pelo positivismo à doutrina kantiana. Para ele é inaceitável a limitação da realidade aos fatos observáveis, o que impede a compreensão do caráter transcendente da ação moral. A sociologia, criada por Comte segundo o método das ciências da natureza, como uma física social, tem como fundamento o conceito kantiano de uma psicologia empírica, mas deixa de lado a consideração da alma como coisa em si.

Influenciado pela atitude crítica de Tobias Barreto, cujo magistério na escola de direito do Recife foi decisivo em sua formação intelectual, Raimundo de Farias Brito (1862-1917) iniciou sua obra filosófica pelo exame crítico das teses do então famoso mestre do Recife. Disto resultou Finalidade do mundo (03 vols.), um apurado estudo sobre a filosofia mo- 
derna do ponto de vista do conhecimento de si, e também $A$ base física do espírito, um estudo crítico da psicologia experimental baseada nas descobertas da biologia e da química.

Aprofundando a ideia inicial de Tobias Barreto sobre a exterioridade do fim que move a ação moral, Farias Brito entende que não basta indagar, kantianamente, se o conhecimento das coisas depende da constituição do nosso espírito; seria preciso verificar também se o conhecimento do eu e da consciência, por sua vez, não sofre a influência do mundo exterior. Neste sentido ele propõe uma psicologia transcendente para dar conta do espírito que não se circunscreve dentro dos limites da previsibilidade, e não se deixa apreender pelos critérios de peso, medida e repetição, mas ao mesmo tempo não se confunde com o conceito solipsista do eu.

Ao assumir a tese de Tobias Barreto, Farias Brito se posiciona no âmbito da cultura moderna contra a "psicologia morta" dos cientistas e a favor da "psicologia viva" dos romancistas e poetas (BRITO 2003, p. 51). Desse modo, ele se coloca, sem o saber, ao lado de Husserl, que à mesma época afirmava que a experiência não pode dizer-nos o que é o ser psíquico no mesmo sentido válido para o físico, e que o psíquico não se experimenta senão como vivência (A filosofia como ciência de rigor).

Correspondendo à tradição do pensamento brasileiro, o eu em Farias Brito não é um eu epistêmico. Para ele, o verdadeiro progresso da filosofia moderna tem uma dimensão metafísica. E é justamente na dimensão metafísica do conhecimento de si que vive o eu como um absoluto, de modo que, para enfatizarmos o significado existencial da posição britiana, não parecerá extravagante se dissermos que o eu está realmente morto, não simbolicamente ou "em certo sentido", ou "como se estivesse", mas literalmente morto, se perde a consciência de si.

Para além do movimento mecânico dos corpos explicado pela física em função de uma "força estranha" ao sujeito, Farias Brito concebe o movimento da vida, envolvendo ideias, intenções e sentimentos próprios, a liberdade enfim, como sendo um movimento gerado pelo pensamento ou espírito enquanto uma outra forma daquela mesma força que o ser humano conhece diretamente no conhecimento de si.

[Do ponto de vista físico] sempre que um corpo se move, é impelido por algum corpo anterior em movimento, quer dizer: obedece à ação de uma força estranha [...] E isto significa que só conhecemos a força em sua aparência material, como movimento ou como corpo deslocando-se no espaço: o que quer dizer precisamente que só conhecemos a força como fenômeno [Mas do ponto de vista metafísico, há] uma força que conhecemos por outra forma, que conhecemos, por assim dizer, diretamente e face a face, ou, mais precisamente, que conhecemos em sua significação interna. É a que reside em 
nós. E esta é de natureza intelectual, pois o que nos determina a agir são necessidades de que temos consciência, são fins que temos em vista realizar (BRITO 2003, p. 366-67)

Não obstante o caráter metafísico de seu pensamento, Farias Brito jamais negou a necessidade de harmonizar a instância do saber filosófico com os últimos resultados da ciência em geral. Para ele, há uma condicionalidade originária entre o "conhece-te a ti mesmo" e a ideia de ciência. Tal condicionalidade configura o ideal grego do saber como algo virtuoso. E se a irrupção do método experimental introduzido pelos físicos modernos implica a necessidade do saber filosófico, a partir do século XVII a ciência se constituiu em condição para toda a atividade filosófica. Kant foi o intérprete dessa condicionalidade entre a ciência e a filosofia, ao estabelecer que o uso metafísico da razão não carece de qualquer ajuda da razão teórica, mas tem de assegurar-se contra a reação desta para não entrar em contradição consigo mesma. E é deste modo que se justificam as seguintes afirmações britianas: que (i) a ciência, que é produto da filosofia, se torna condição da filosofia, e que (ii) cada filósofo sofre a influência de uma ciência a cuja inspiração obedece, mas sempre que se dedica à atividade filosófica, o que procura é interpretar o espírito.

No Brasil do século XIX, após dois séculos de ensino filosófico sob a Ratio Studiorum, era da maior importância compreender a diferença entre conhecimento e fé. Neste sentido, ao posicionar-se radicalmente contra a pretensão dos naturalistas e positivistas de estender o método das ciências da natureza ao conhecimento do psíquico, Farias Brito nada tem a ver com o perfil escolástico dos metafísicos à moda antiga. Outra foi a sua motivação: ele levou às últimas consequências a tese kantiana segundo a qual somente pela consideração da vontade como pertencente a uma coisa em si, isto é, a alma humana não sujeita à causalidade mecânica, podemos compreender em que sentido a liberdade é princípio de ação moral. Contrariamente a Kant, porém, ele conferiu uma significação positiva ao conceito da "coisa em si". Para ele, o que sem dúvida está em jogo é a ação moral em sua intencionalidade própria de um espírito que é a um só tempo livre e criador. A compreensão do espírito a partir de seu "poder agente e real, vivo e concreto, que não somente sofre a ação dos elementos exteriores, como ao mesmo tempo é capaz de agir sobre eles" (BRITO 2003, p. 60) define a vida do espírito do ponto de vista dele mesmo, considerado em si, e jamais como um fenômeno físico ou mesmo psicofísico.

Mais uma vez, ressalte-se aqui o paralelismo de seu pensamento com o de Husserl, para quem o erro do naturalismo consiste em querer fazer com que a percepção do psíquico seja objetiva, como é próprio da expe- 
riência física, quando, na verdade, as leis inerentes à esfera do psíquico são inteiramente distintas das existentes na esfera do mundo físico. Desse modo, o fracasso naturalista se deve à ingenuidade de ater-se a comprovações experimentais que não se referem senão a fenômenos sensíveis e subjetivos que devem ser descritos e caracterizados com precisão, o que não os leva, em hipótese alguma, a atingir a verdadeira esfera da consciência. Com efeito, tudo o que é eminentemente psicológico, e que diz respeito à verdadeira esfera da consciência se perde em meio a análises ocasionais. Tais análises não podem levar em consideração a especificidade do psíquico. Farias Brito defende claramente a impossibilidade de a ordem psíquica ser concebida em analogia com a dos "fenômenos naturais", pois esta e aquela se apresentam como dois absolutos.

Sendo justificável o paralelismo com Husserl em função do esclarecimento do problema central, importa nomear os autores que efetivamente foram referências constantes na trajetória do pensamento de Farias Brito: Schopenhauer e Henri Bergson. Abrindo-lhe uma janela para a filosofia oriental, e suscitando um interesse especial na doutrina do Buda, o alemão foi a ponte através da qual ele chegou a determinar a sua visão da dor como problema filosófico; já o francês foi decisivo para ele fundamentar a distinção entre a intuição de objetos e fatos empíricos e a intuição de estados e fatos de consciência. Advirta-se, porém: ele não foi sectário de nenhum dos dois.

É interessante observar que tanto Schopenhauer quanto Bergson foram arrolados por Farias Brito como anti-intelectualistas. São ambos filósofos que, em Farias Brito, contribuem decisivamente para a compreensão de que "nada tem mais alta eficácia prática que a metafísica" (BRITO 2006, p. 110), pois a ciência do espírito que ele propõe "não se aprende nos livros, mas na luta mesma da vida: é uma ciência que, por assim dizer, não se aprende, mas vive-se; ciência que faz parte orgânica daquele que a possui, e em que o objeto do conhecimento é consubstancial com o sujeito" (BRITO 2003, p. 70). Assim, como fundamento da experiência, o que ele chama de "psicologia transcendente", para dar conta do caráter metafísico do saber, pode ser considerado no mesmo sentido da "psicologia transcendental" de Husserl.

No Brasil, é a consideração do espírito em separado da matéria o que faz da liberdade a evidência do espírito humano e, assim, o que propicia a visão do espírito enquanto energia viva e criadora. E é por esta razão, exclusivamente, que Farias Brito defende o método introspectivo como método filosófico: "A este método [...] tem-se feito, e ainda se continua a fazer, uma oposição formidável. É o que se explica como conseqüência inevitável, fatal do predomínio do materialismo. E realmente, se tudo é matéria, não se compreende outra espécie de observação a não ser a 
observação exterior" (idem, p. 408-409). Isto não quer dizer, entretanto, que ele não tivesse considerado o perigo do solipsismo:

E ainda há a distinguir a introspecção direta e a introspecção indireta [...] Se não houvesse outra observação psíquica, além desta, o resultado seria o solipsismo [...] De uma para outra consciência não há, por certo comunicação por processo interno. Cada uma é, sob este ponto de vista, um todo isolado e forma, a seu ponto de vista, o centro do mundo; mas há entre as diferentes consciências comunicação segura, positiva e certa por processo exterior. Tal é, por exemplo, a palavra, a linguagem em geral, como qualquer sinal com que se possa dar expressão ao pensamento. Além disto, os estados de alma refletem-se por sinais evidentes no próprio organismo. Uma emoção profunda comove até às lágrimas. $\mathrm{O}$ olhar fala. A raiva empalidece [...] Todos estes fatos autorizam a formar juízos seguros sobre sentimentos e ideias, emoções e paixões a que somos estranhos e que se passam em consciências estranhas à nossa. (Idem, p. 419-20)

Farias Brito é a síntese da experiência histórica de pensar do povo brasileiro. Em sua obra distingue-se claramente o problema da filosofia em sua historicidade. Trata-se da necessidade do conhecimento de si. Seu estudo crítico dessa instância do saber na era da ciência, o caráter metafísico desse estudo, não só incorpora e amplia as ideias apresentadas pelos seus antecessores no Brasil, especialmente Antônio Vieira, Gonçalves de Magalhães e Tobias Barreto, como confere à expressão "filosofia brasileira" um significado verdadeiramente filosófico.

\section{Conclusão}

O estudo crítico do aristotelismo da Ratio Studiorum é imprescindível à noção de filosofia brasileira. Sem prejuízo do conceito de aristotelismo, que remonta à filosofia medieval, particularmente à Escolástica, o aristotelismo de origem ibérica constitui-se numa tradição filosófica dentro da qual a filosofia emancipou-se no Brasil. Além do interesse específico na história do aristotelismo, e do interesse genérico na história da filosofia ocidental, por causa de sua posição crucial entre aristotélicos e antiaristotélicos no limiar da filosofia moderna, o aristotelismo ibérico também desperta interesse tanto nos Conimbricenses, como na obra de autores como Francisco de Vitória, Domingo de Soto, Juan Luis Vives, Pedro da Fonseca, Luis de Molina, Domingo Báñez e Francisco Suárez.

Enquanto autor religioso, o Pe. Antônio Vieira não questionou o caráter tutelado do ensino filosófico sob a Ratio Studiorum. Entretanto, ele foi levado a pensar a eficácia das próprias ações como problema a partir da 
conversão. Seu conceito da conversão constitui-se numa abertura para a ideia da filosofia como sendo o conhecimento de si desde o "conhece-te a ti mesmo" socrático. Desse ponto de vista, a obra do jesuíta Antônio Vieira adquire, para além do seu sempre renovado interesse literário, uma significação nova para a história da filosofia no Brasil.

Mais do que quaisquer outros que o tenham antecedido, incluindo-se o Frei Francisco do Monte Alverne e o português Silvestre Pinheiro Ferreira, que promoveram a inserção da cultura brasileira nos quadros da filosofia moderna, Gonçalves de Magalhães foi o primeiro a pensar a modernização da cultura brasileira como problema filosófico.

Tobias Barreto foi o verdadeiro responsável pela definitiva superação do aristotelismo no Brasil. Ele não só assimilou a dimensão metafísica da doutrina de Kant, como chegou a esboçar uma teoria da cultura como fundamento da modernização no Brasil, o que o levou a assumir uma posição contrária à ciência da alma que não leva em conta o seu caráter transcendente na ação moral.

A obra filosófica de Farias Brito significa o coroamento dessa experiência de pensar que representa o nascimento da filosofia brasileira. Seu aprofundamento no estudo da filosofia moderna e a sua proposta de uma "ciência do espírito" como princípio de todo o saber, não só incorporam e ampliam as teses apresentadas pelos antecessores, como colocam o pensamento brasileiro na perspectiva do pensamento filosófico contemporâneo no que diz respeito a tematizações de caráter existencial e à fenomenologia como método.

Para nós, este modo de ver uma relação originária entre Antônio Vieira, Gonçalves de Magalhães, Tobias Barreto e Farias Brito, como referência básica para a compreensão da ontogênese da consciência de si no Brasil, estabelece as condições suficientes e necessárias para uma verdadeira história da filosofia no Brasil.

\section{REFERÊNCIAS BIBLIOGRÁFICAS}

ALMADA, Leonardo Ferreira. A ideia de filosofia como ciência do espirito no Brasil. 2009. 172 p. Tese (doutorado em Filosofia) - Universidade Federal do Rio de Janeiro, Rio de Janeiro, 2009.

http://textosdefilosofiabrasileira.blogspot.com/2009/03/ideia-de-filosofia-comociencia-do.html

BARRETO, Tobias. Estudos de filosofia. In: Obras completas. Introdução e notas de Paulo Mercadante e Antônio Paim; biobibliografia de Luiz Antônio Barreto. Rio de Janeiro: Record/INL, 1990. 
BRITO, R. H. da Silva. A crítica do naturalismo na filosofia brasileira do século XIX. 2006. 124 p. Dissertação (Mestrado em Filosofia) - Universidade Federal do Rio de Janeiro, Rio de Janeiro, 2006.

http://www.cipedya.com/web/FileDetails.aspx?IDFile=161200

BRITO, R. de Farias. Finalidade do mundo (Estudos de filosofia e teleologia naturalista), em 3 volumes; primeiro volume: A filosofia como atividade permanente do espírito (1895); segundo volume: A filosofia moderna (1899); terceiro volume: $O$ mundo como atividade intelectual (1905a). Rio de Janeiro: INL, 1957.

. A verdade como regra das ações (1905b). Introdução de Antônio Carlos Klein. Brasília: Senado Federal, 2005.

. A base física do espirito - História sumária do problema da mentalidade como preparação para o estudo da filosofia do espirito (1912). Brasília: Senado Federal, 2006.

. O mundo interior - Ensaio sobre os dados gerais da filosofia do espirito (1914). Lisboa: INCM, 2003.

Inéditos e dispersos (Notas e variações sobre assuntos diversos). Compilação de Carlos Lopes de Mattos. São Paulo: Grijalbo/EDUSP, 1966.

CERQUEIRA, L. A. Filosofia brasileira - Ontogênese da consciência de si. Petrópolis: Vozes, 2002.

. Gonçalves de Magalhães como Fundador da Filosofia Brasileira. In: Fatos do espirito humano. Petrópolis: Vozes-Academia Brasileira de Letras, 2004.

_. Natureza e Cultura em Tobias Barreto. In: Textos de Filosofia Brasileira. http://textosdefilosofiabrasileira.blogspot.com/2009/12/natureza-e-cultura-em-tobias-barreto.html

. O Aristotelismo como Tradição Originária da Filosofia no Brasil. Anais do III Seminário Internacional Farias Brito. Rio de Janeiro: UFRJ, 2009.

http://filosofiabrasileiracefib.blogspot.com/2010/01/o-aristotelismo-como-tradicao. html

. Maturidade da Filosofia Brasileira: Farias Brito. In: BRITO, R. De Farias, O mundo interior. Lisboa: INCM, 2003.

A Ideia de Modernização no Brasil sob o Influxo da Filosofia Política de Rousseau. Anais do II Seminário Internacional Farias Brito. Rio de Janeiro: UFRJ, 2008.

http://iiseminariofariasbrito.blogspot.com/2008/09/idia-de-modernizao-no-brasilsob-o.html

COMPAÑIA DE JEÚS. Reglas del Professor de Filosofía. Ratio Studiorum Oficial 1599. Traducción de Gustavo Amigó, S.J., revisada por Dr. Daniel Álvarez, S.J.

http://www.puj.edu.co/pedagogia/documentos/Documentos_Corporativos_Compania_Jesus.pdf 
COXITO, A. Estudos sobre filosofia em Portugal no século XVI. Lisboa: INCM, 2005.

. Estudos sobre filosofia em Portugal na época do Iluminismo. Lisboa: INCM, 2006.

DESCARTES, R. Princípios da filosofia (edição bilíngue). Tradução de Guido Antônio de Almeida (coord.). Rio de Janeiro: UFRJ, 2002.

. Oeuvres. Edição organizada por C. Adam e P. Tannery. Paris: Vrin/CNRS, 1964-1976.

D. DUARTE. Leal conselheiro. In: Obras dos Príncipes de Avis. Porto: Lello, 1981.

D. JOÃO. Livro da montaria. In: Obras dos Príncipes de Avis. Porto: Lello, 1981.

D. PEDRO. Da virtuosa benfeitoria. In: Obras dos Príncipes de Avis. Porto: Lello, 1981.

FERREIRA, Silvestre Pinheiro. Prelecções filosóficas. Introdução de José Esteves Pereira. Lisboa: INCM, 1996.

FONSECA, Pedro da. Instituições dialécticas (02 vols.). Introdução, estabelecimento do texto latino, tradução e notas por Joaquim Ferreira Gomes. Coimbra: Universidade de Coimbra, 1964.

_. Commentariorum in libros Metaphysicorum Aristotelis Stagiritae. Hildesheim (reimp.), 1964.

. Isagoge filosófica. Introdução, edição do texto latino e tradução por Joaquim Ferreira Gomes. Coimbra: Universidade de Coimbra, 1965.

LOPES, Roberto (org.). Cartas a Monte Alverne (remetidas por Araújo Porto Alegre e Gonçalves de Magalhães). São Paulo: Conselho Estadual de Cultura, 1964.

MAGALHÃES, D. J. Gonçalves de. Prólogo "Lede". In: Suspiros poéticos e saudades. Paris: Dauvin et Fontaine, 1836.

. Ensaio sobre a História da Literatura do Brasil. Fatos do espírito humano. Petrópolis: Vozes-Academia Brasileira de Letras, 2004.

. Filosofia da Religião. Fatos do espirito humano. Petrópolis: Vozes-Academia Brasileira de Letras, 2004.

. Fatos do espírito humano. Petrópolis: Vozes-Academia Brasileira de Letras, 2004.

. A alma e o cérebro - estudos de psicologia e fisiologia. Rio de Janeiro: Garnier, 1876.

_ (editor). Niterói, Revista Brasiliense. Ciências, Letras e Artes (1836). São Paulo: Biblioteca Academia Paulista de Letras (vol. 9), 1978.

MARTINS, António Manuel. A Liberdade como Princípio em Pedro da Fonseca. Anais do I Seminário Internacional Farias Brito. Rio de Janeiro: UFRJ, 2007.

http://iseminariofariasbrito.blogspot.com/2008/06/liberdade-como-princpio-empedro-da.html 
Liberdade e Autonomia em Fonseca. Mediaevalia, Textos e Estudos, 7-8. Porto, 1995, pp. 515-27.

A Recepção da Metafísica de Aristóteles na Segunda Metade do Século XVI. In: CERQUEIRA, L.A. (org.) Aristotelismo Antiaristotelismo Ensino de Filosofia. Rio de Janeiro: Ágora da Ilha, 2000, pp. 93-109.

ROMERO, Sílvio. A Poesia de Hoje. In: Cantos do fim do século, Prólogo. Rio de Janeiro, 1978a. - A filosofia no Brasil. Porto Alegre, $1878 \mathrm{~b}$.

. Explicações Indispensáveis. In: BARRETO, Tobias. Vários escritos. Obras completas. Rio de Janeiro, 1926.

VERNEY, Luís António. Metafísica. Fixação do texto latino por Sebastião Tavares de Pinho e Andria Patrícia Seiça. Introdução e tradução de Amândio Coxito. Coimbra: Universidade de Coimbra, 2008.

Verdadeiro método de estudar. Edição organizada por António Salgado Júnior. Lisboa: Sá da Costa, 1952.

VIEIRA, Padre Antônio. Sermões (vols. I e II). Organização de Alcir Pécora. São Paulo: Hedra, 2001. 